\title{
Creditor-Focused Corporate Governance: Evidence from Mergers and Acquisitions in Japan
}

\author{
Vikas Mehrotra, Dimitri van Schaik, Jaap Spronk, \\ and Onno Steenbeek*
}

\begin{abstract}
Mergers in Japan have the dubious distinction of not creating wealth for shareholders of target firms, in sharp contrast to what occurs in much of the rest of the world. Using a sample of 91 mergers from 1982 through 2003 we document several distinctive features of the merger market in Japan: Mergers tend to be countercyclical and appear to be driven chiefly by creditor concerns. In particular, where the merging firms share a common main bank, we find that merger gains are lower. Overall, our results point to a market that is distinctly less shareholder focused than that in the U.S., and a market where creditors play an important, perhaps dominant, role in corporate governance.
\end{abstract}

\section{Introduction}

Mergers in Japan stand out in not creating wealth for the selling firm's shareholders. Wealth gains in the immediate window surrounding merger announcements are insignificant for target firms in Japan; indeed, they are also insignificant for bidders, whereas for much of the rest of the world target shareholders enjoy significant valuation increases, and bidding shareholders appear to break even, give or take. ${ }^{1}$ In this paper we analyze why Japanese mergers fail to create

\footnotetext{
*Mehrotra, vikas.mehrotra@ business.ualberta.ca, School of Business, University of Alberta, 4-20J Business Bldg., Edmonton, AB, T6G 2R6, Canada; van Schaik, vanschaik_d@hotmail.com, Teijin Aramid, PO Box 5153, 6802 ED, Arnhem, The Netherlands; Spronk, jspronk@rsm.nl, Rotterdam School of Management, Erasmus University Rotterdam, PO Box 1738, Rotterdam, 3000 DR, The Netherlands; and Steenbeek, steenbeek@ese.eur.nl, Erasmus School of Economics, Erasmus University Rotterdam, PO Box 1738, Rotterdam, 3000 DR, The Netherlands, and ALM and Risk Department, APG All Pensions Group, The Netherlands. We thank an anonymous referee, Richard Beason (a referee), and Paul Malatesta (the editor) for helpful comments.

${ }^{1}$ For the European merger experience, see Martynova and Renneboog (2006); for the U.S., see Jensen and Ruback (1983), Jarrell and Poulsen (1989), and Andrade, Mitchell, and Stafford (2001); and for Japan, see review in this paper in Section II.
} 
wealth for either of the merging firms, and what role creditors might play in this process. Specifically, we examine the role played by the main bank in merger activity in Japan, and address the possibility that main bank objectives (e.g., rescue-motivated mergers) are associated with the lackluster wealth effects documented for Japanese mergers. More generally, our study offers insights into the costs imposed on shareholders of creditor-centric corporate governance models. While the benefits of such a system have been noted extensively in the literature (partial review follows), the costs imposed on shareholders have not been accorded the same degree of scrutiny.

Given recent turmoil in the financial sector, with its epicenter being Wall Street firms, interest in alternative corporate governance forms is increasing. A natural question is whether creditor-centric corporate governance norms, as opposed to the U.S.-style shareholder-focused governance practices, are better suited to protect the small investor on the premise that creditors such as banks are superior monitors of management and, where they have leverage over borrowers, can exercise this power judiciously. The Japanese main bank system is an excellent setting in which to examine this claim. The main bank system is described elsewhere in detail (see, e.g., Morck and Nakamura (1999)); its chief features are the presence of a main bank at the center of a business group linked to its members via cross shareholdings (so-called financial keiretsu). The main bank is often the chief lender to group firms, and though its equity stake in group firms is generally capped at $5 \%$, the main bank has traditionally exercised considerable control over group firms, particularly in times of financial difficulty. ${ }^{2}$

The notion that Japanese corporate governance caters more to creditors than to equity holders is not new. For instance, Morck and Nakamura (1999) show that main banks act first and foremost in the interest of creditors; when shareholder interests are attended to, it is done as part of a larger stakeholder group to which the main bank owes uniform allegiance. Bankers are appointed to the boards of directors of firms with cash flow problems, not to firms with sub-par stock price performance. Aoki (1990) and Kaplan (1994) argue that banks exercise considerable influence over Japanese executives, and so long as the debtor firms generate sufficient earnings to meet debt payments, managers are allowed to run their firms in their own and their employees' interests without much interference from the main bank. Aoki (2000) is more direct, arguing that main banks essentially have veto power over a firm's key investment decisions when the firm encounters financial difficulties. Flath (1990) shows that Japanese banks' lending to and shareholdings in a borrower firm are positively related and concludes that such arrangements help overcome standard agency costs of debt. Similarly, Prowse (1990) shows that several types of agency costs of debt financing are mitigated in Japan due to the practice of creditors, especially main banks, taking on equity stakes in borrower firms. Hoshi, Kashyap, and Scharfstein (1990) provide evidence consistent with an efficiency rationale for group as well as main bank lending to distressed firms. Aoki, Patrick, and Sheard (1994) find that firms

\footnotetext{
${ }^{2}$ See, for example, Aoki (1990) and Sheard (1989), who provide evidence that Japanese main banks discipline poorly performing managers. Kang and Shivdasani (1996) document how main banks appoint directors to group firms' boards when the borrower firm experiences financial difficulty.
} 
affiliated with a horizontal keiretsu are more efficiently monitored by the main bank because short-term bank loans help reduce information asymmetry between the lender and the borrower.

Despite these advantages, banks' monitoring role has been questioned by Hanazaki and Horiuchi (2000). Kang and Stulz (2000) show that bank involvement for a firm was associated with lower performance in the 1990s. Moreover, Sheard (1989) argues that the main bank is perceived by other lenders as the residual risk bearer in its client firm, and in case of financial distress or default, is frequently expected to absorb a disproportionate share of losses. There appears to be little upside in this role, in contrast to that of a standard residual risk bearer such as an equity holder; hence, main banks may well pressure 2 client firms to merge if 1 of them is financially distressed. In fact, Morck and Nakamura (1999) conclude that the main bank in a financial keiretsu frequently "props up" weak member firms. Their evidence supports the "bank power hypothesis" that maintains that corporate governance in Japan pays scant heed to residual claimant interests and is largely motivated by protecting the contractual fixed claims of creditors.

Our sample contains 91 mergers between listed firms in the period 19822003. We examine whether the main bank has a role in the economics of merger activity in Japan, especially in cases where 1 of the merging firms is financially weak. We argue that a main bank, holding primarily fixed contractual claims on the borrower, is more likely to get involved in mergers when 1 of the merging firms is in financial distress or, more generally, during economic downturns. In the former case, when borrowers encounter financial difficulties, the main bank is more likely to propose a rescue merger with a financially strong client as part of its restructuring plan.

Prior research on Japanese mergers has examined the influence of the main bank by primarily focusing on the bidder firm. This is partly driven by the nature of mergers in Japan, where many target firms are unlisted entities. One exception is the study by Kang, Shivdasani, and Yamada (2000) that includes exchangelisted target firms, but their focus remains the buying firms: They find that bidders are unlikely to overpay for targets, as they can take advantage of the information possessed by the common main bank.

Our analysis includes listed target firms, among which many are financially weak and likely to impair the collateral of loans held by the main bank. When faced with a delinquent borrower, the main bank, to the extent it has the power to do so, is motivated to look for rescue candidates in the guise of financially sound bidders who can be coaxed into merging with the financially weak target firms. Borrowing from Morck and Nakamura (1999), we label the influential role of banks in Japanese corporate governance the "bank power hypothesis." A prediction of the bank power hypothesis is that the presence of a common main bank is more likely to be associated with mergers involving a financially weak firm with a financially strong firm. A corollary of the bank power hypothesis is that main banks are less likely to get involved in mergers where both the target and the bidder firms are in financial distress.

In our examination of merger-related wealth effects for shareholders, we pay special attention to specific macroeconomic conditions, such as the phase of the business cycle and changes in the external regulatory structure. Specifically, we 
examine the following subperiods: i) 1982-1989 (1980s), ii) 1990-1996 (early 1990s), and iii) 1997-2003 (late 1990s). The 1980s are characterized by an average annual gross national product (GNP) growth of 5.5\% and represent an era when firms made substantial investments in capital assets and real estate. The investment was associated with significant price appreciation both in the stock market and in real estate in the late 1980s. As is well known, the stock market bubble burst at the end of 1989 and the real estate bubble soon thereafter. This crash of both the stock market and real estate market marks the end of our 1st subperiod. During the 2nd subperiod, the early 1990s, economic growth slowed down considerably, with GNP growth dropping to an annual average of 1.5\%. A large number of firms faced financial difficulties, and several large banks coped with nonperforming loans (NPLs). A problem during this period was the unwillingness of banks to come to terms with the NPL crisis, perhaps in the expectation that when the financial and real estate markets rebound, the banks' balance sheets would recover.

The 3rd subperiod, the late 1990s, is typified by the aggravation of the financial difficulties and witnessed various amendments to laws related to mergers and acquisitions (M\&A) and ownership, such as the lifting of the ban on pure holding firms. In 1997 the severity of the NPL problems of Japanese financial institutions became evident with the bankruptcies of the Hokkaido Takushoku Bank and Yamaichi Securities Company, and the Long-Term Credit Bank of Japan and Nippon Credit Bank in 1998 and 1999. Consolidated accounting and reporting requirements of investments at market value put pressure on firms to divest their shareholdings in other firms and banks (see, e.g., Miyajima and Fumiaki (2005)). The unwinding of shares by firms, combined with the banking crisis in 1997, subsequently resulted in banks selling their cross shareholdings in firms (see Scher (2001), Miyajima and Fumiaki).

Overall, our findings are consistent with the view that mergers in Japan are driven less by efficiency gains, and indeed are largely a means to protect the fixed contractual claims of creditors. This view of a creditor-focused governance model is consistent with the evidence and inferences in Morck and Nakamura (1999) and calls into question the broader appeal of governance models that forsake explicit references to shareholder welfare in favor of other stakeholder groups.

The rest of this paper is organized as follows. In Section II we provide a brief survey of recent evidence on merger activity in Japan. In Section III we describe our data collection process and sources. Section IV contains a description of the asset characteristics for our sample firms. Our main results are provided in Section $\mathrm{V}$, and conclusions are in Section VI.

\section{Previous Research on Mergers in Japan}

In this section we review the literature on the time-series properties of mergers in general, and more specifically, on the empirical evidence surrounding the wealth effects of Japanese mergers. We start by examining why mergers tend to take place in waves. The neoclassical view is that mergers are a response to resource allocation questions raised in times of technological and regulatory changes. An alternative view treats mergers as a byproduct of stock market 
overvaluations that permit bidders to expand their control via the use of overvalued stocks as currencies in the merger market. In Section II.B we summarize the evidence on bidder and target firm returns in Japan. This evidence essentially shows that over short windows surrounding the merger announcements in Japan, both bidder and target firms experience statistically and economically insignificant wealth effects.

\section{A. Merger Waves}

Shleifer and Vishny (2003) propose a model of mergers where stock overvaluation encourages firms to acquire assets using their own stock as currency; if stock overvaluation and overall market peaks tend to coincide, their model provides a ready explanation for merger waves. Du Boff and Herman (1989) also conclude in favor of a strong link between market overvaluation and merger activity, although they do not examine the welfare implications for bidders formally, and ascribe rent-seeking motives for promoters of mergers. More traditionally, Mitchell and Mulherin (1996) argue that mergers result from shocks to an industry's economic, technological, or regulatory environment, and are an efficient way to allocate assets following such shocks. Harford (2005) adds that sufficient capital liquidity is necessary to accommodate reallocation of assets, and that liquidity tends to be procyclical. Andrade and Stafford (2004) ascribe a dual role for mergers, both expansionary in a manner similar to internal capital investments at the firm level, and contractionary in the face of industry shocks. A negative business cycle can cause financial difficulties for firms, resulting in corporate bankruptcies or rescue mergers of failing firms (see Nelson (1959)).

We note that mergers can have both a positive and a negative effect on bidder valuations. These have been examined extensively in the literature. ${ }^{3}$ Our interest here is on studying the role of creditors in the merger process. Specifically, we examine whether a rescue merger can be seen as an alternative to bankruptcy for 1 of the merging firms (more often the target firm; see, e.g., Weston and Mansinghka (1971), Melicher and Rush (1974)).

\section{B. Japanese Mergers: The Empirical Evidence}

Previous research on Japanese domestic mergers shows that bidder firms enjoy a positive stock price runup until the merger announcement date (AD), but this effect turns negative thereafter. Similar results are found for target firms: The preannouncement abnormal returns for target firms are only marginally larger than those for bidders, with postannouncement returns reversing the prior gains. This evidence is surveyed in Figure 1.

\section{Bidder Returns Surrounding Merger Announcements}

Pettway and Yamada (1986) examine 16 mergers in the period from 1977 to 1984 and find positive abnormal returns preceding the $\mathrm{AD}$ for bidder firms.

\footnotetext{
${ }^{3}$ See among others, Berkovitch and Narayanan (1993), Bradley, Desai, and Kim (1988), Goergen and Renneboog (2004), Roll (1986), and Malmendier and Tate (2008).
} 
FIGURE 1

A Survey of Wealth Effects of Merger Announcements in Japan

\begin{tabular}{|c|c|c|c|c|c|c|c|c|c|c|c|c|c|}
\hline Study & Years & CAR & -5 & -4 & -3 & -2 & -1 & $A D$ & 1 & 2 & 3 & 4 & 5 \\
\hline \multicolumn{14}{|c|}{ Bidder Company } \\
\hline Pettway and Yamada (1986) & $1977-1984$ & $0.70 \%$ & & & & & & & & & & & \\
\hline Ito (1989) & 1971-1987 & $1.15 \%$ & & & & & & & & & & & \\
\hline Kang et al. (2000) & $1977-1993$ & $1.17 \%$ & & & & & & & & & & & \\
\hline Komoto (2002) & $1980-1999$ & $-2.10 \%$ & & & & & & & & & & & \\
\hline Yeh and Hoshino (2002) & $1981-1998$ & $-1.01 \%$ & & & & & & & & & & & \\
\hline Yeh $(2007)^{a}$ & $1981-1998$ & $-0.34 \%$ & & & & & & & & & & & \\
\hline \multicolumn{14}{|c|}{ Target Company } \\
\hline \multirow[t]{3}{*}{ Pettway and Yamada (1986) } & $1977-1984$ & $1.33 \%$ & & & & & & & & & & & \\
\hline & & $-0.07 \%$ & & & & & & & & & & & \\
\hline & & $-0.86 \%$ & & & & & & & & & & & \\
\hline \multirow[t]{3}{*}{ Ito (1989) } & $1971-1987$ & $1.26 \%$ & & & & & & & & & & & \\
\hline & & $-2.85 \%$ & & & & & & & & & & & \\
\hline & & $-1.75 \%$ & & & & & & & & & & & \\
\hline Komoto (2002) & 1980-1999 & $-4.90 \%$ & & & & & & & & & & & \\
\hline
\end{tabular}

The abnormal return for day [-1] is $0.60 \%$ and statistically significant at conventional levels, and the cumulative abnormal return (CAR) for the 2-day period $[-1,0]$ is $0.70 \%$, but statistically insignificant. Ito (1989) investigates 31 mergers between listed firms in the period from 1971 to 1987 , covering the sampling period of Pettway and Yamada. He finds that abnormal returns for bidders are significant $(+1.15 \%)$ for the 2-day window spanning $[-1,0]$ but display reversals and turn statistically insignificant when the postannouncement measurement window is expanded. The results for the expanded postannouncement window are confirmed by Komoto (2002) using a sample of 88 mergers in Japan from 1980 to 1999 ; that paper reports a negative abnormal return of $-2.1 \%$ for an 11 -day window spanning $[-5,+5]$. Yeh and Hoshino (2002) investigate 89 mergers in the period 1981-1998 and find a significantly negative abnormal return for bidder firms of $-1.01 \%$ for the event period $[-1,+1]$. Yeh (2007) examines both mergers and tender offers during the period from 1981 to 1998 and finds a significantly positive return of $1.44 \%$ for the event window $[-10,+1]$. However, the 3-day abnormal return centered on the AD is not significant. Kang et al. (2000) investigate bidder returns over the period from 1977 to 1993 and report a 2-day abnormal return of $1.17 \%$ for the window $[-1,0]$.

Overall, the bidder experience in Japan appears similar to that observed in the U.S. and other countries; that is, bidders experience small wealth effects 
surrounding merger announcements ranging from marginally negative to 0 . We next turn to target firm wealth effects around merger announcements.

\section{Target Firm Returns Surrounding Merger Announcements}

As noted earlier, the evidence on the wealth effects for target firms is sparser, since most studies focus on bidders and include unlisted targets. Below we summarize the evidence on exchange-listed target firms. Pettway and Yamada (1986), using a sample of 16 mergers, find a significant abnormal return of $1.57 \%$ on day -1 , and a significant negative abnormal return of $-1.4 \%$ on day +1 , where day 0 is the merger $\mathrm{AD}$. The resulting abnormal return for the period $[-1,+1]$ is $-0.07 \%$ and statistically not significant. Returns over longer interval are generally negative and statistically insignificant (e.g., the CAR over an 11-day window centered on the merger AD is $-0.86 \%$ ). Ito (1989) finds similar results using a sample of 31 target firms; the merger announcement return for the event period $[-1,0]$ is $1.26 \%$ but reverses and turns negative for event windows $[-1,+1]$ and $[-5,+5]$ $(-2.85 \%$ and $-1.75 \%)$. Komoto (2002) reports a negative abnormal return of $-4.9 \%$ for target firms for an 11-day window centered on the merger AD.

The evidence on merger returns in Japan suggests the following stylized facts: First, preannouncement returns for both bidders and target firms appear to be positive, though small in magnitude, and certainly smaller for target firms when compared to similar evidence in the U.S. ${ }^{4}$ Second, when the event window is expanded to include postannouncement days, the earlier price runup is largely reversed. And finally, target returns are conspicuously smaller over all return windows relative to their U.S. counterparts.

The involvement of banks in the merger process has received limited attention in the literature. Kang et al. (2000) investigate bidder returns in mergers with 108 unlisted targets and 46 listed targets during the period 1973-1993. They find significant positive abnormal returns for bidder firms affiliated with a main bank and conclude that the main bank enhances shareholder wealth. More recent research, although not primarily focused on the role of the main bank, presents somewhat different results on merger motives. Arikawa and Miyajima (2007) conclude that mergers during the period from 1991 to 2004 in Japan were largely motivated by industry-level economic shocks. They find that target firms during this period tended to have lower growth opportunities and higher leverage, which suggests that mergers may have been used as a means of corporate restructuring during this period. Arikawa and Miyajima conclude that the increase in concentration in the financial sector has had a perverse impact on weak borrowers by increasing their reliance on main banks, while reducing the reliance of strong borrowers on the main bank system. Their findings point to an overall weakening of the asset quality in the main bank system. Kruse, Park, Park, and Suzuki (2007) investigate 69 mergers of firms listed on the Tokyo Stock Exchange (TSE) during the period from 1969 to 1999 and find that operating performance improves following mergers, especially for cross-industry mergers. Lin, Michayluk, Oppenheimer, and Reid (2008) examine whether bidder firms in Japan are motivated by hubris

\footnotetext{
${ }^{4}$ See among others, Langetieg (1978), Servaes (1991), and Kaplan and Weisbach (1992).
} 
and conclude that overconfident managers are more likely to be associated with value-destroying mergers.

Our study specifically examines the bank power hypothesis of merger activity in Japan. Our main prediction is that mergers between firms sharing a common main bank are less likely to create wealth for shareholders, and that such deals are more likely to involve merging a financially strong firm with a weak firm, with the chief aim of protecting the main bank's loan assets.

\section{Data}

We examine domestic mergers between nonfinancial firms listed on the 1st or the 2nd section of the TSE in a 22-year period from January 1982 through December 2003. We start by collecting information on all firms that were delisted from TSE during this period. Next, we investigate whether the delisted firms were involved in a merger by examining all press articles related to mergers in the period from 1982 to 2003. The press articles are from the Nihon Keizai Shimbun [Japan Economic Journal], Nikkei Sangyo Shimbun [Industrial Journal], Nikkei Ryutuu Shimbun [Distribution Journal], and Nikkei Kinyuu Shimbun [Finance Journal]. If the firm was engaged in a merger, we collect the initial public $\mathrm{AD}$ and the effective date (ED) of the merger from the press articles. The AD is defined as the 1st press date of the merger announcement. We obtain accounting data from NEEDS (Nikkei Economic Electronic Databank System) and stock price data from FactSet.

Our final sample contains 91 mergers over the period $1982-2003 .{ }^{5}$ Figure 2 and Table 1 show the distribution of mergers over the sampling period. We pay special attention to 3 subperiods in our sample. Nineteen mergers of our total sample occur in the 1980s, 21 in the early 1990s, and 51 in the late 1990s. The last period, spanning 1997-2003, accounts for more than $1 / 2$ of our sample. We also note a special characteristic of mergers during our sampling period: Merger activity appears to be countercyclical to the stock market valuation as measured by the Nikkei Index, in sharp contrast to the experience in the U.S. ${ }^{6}$

Following Kang et al. (2000), we use the publication Kigyo keiretsu Soran for the year of the merger announcement to define a main bank as the firm's most important lender while also belonging to the firm's 5 largest shareholders. Based on this definition, we find (see Table 1) that $67 \%$ of target firms and $65 \%$ of bidder firms have a main bank relationship. This compares with $72 \%$ of firms having a main bank relationship across all Japanese firms listed on the 1st section of the TSE in 1980 (Sheard (1989)). In 31\% of mergers the target and bidder firms have

\footnotetext{
${ }^{5}$ We note that prior studies have included unlisted targets in the sample. Since our study aims to examine wealth effects on both target as well as bidder firms, we focus only on listed firms. Our analysis of bidder returns in Section $\mathrm{V}$ shows that these are comparable to those involving unlisted targets documented in prior literature.

${ }^{6}$ Several researchers have noted a positive link between mergers and business cycles (Nelson (1959)) and mergers and stock market valuation (Andrade et al. (2001), Rhodes-Kropf and Viswanathan (2004)) using U.S. data. A common feature of this evidence is that merger intensity appears to increase with economic expansion, and that the use of stock financing in mergers appears to peak in line with stock market valuations.
} 
FIGURE 2

Merger Activity in Japan from 1981 through 2003

In Figure 2, the number of mergers is plotted on the left vertical axis, and the Nikkei Index (year-end value) is plotted on the right vertical axis. The sample consists of 91 mergers between bidder and target firms listed on the Tokyo Stock Exchange for which the announcement date of the merger is between 1 January 1982 and 31 December 2003.

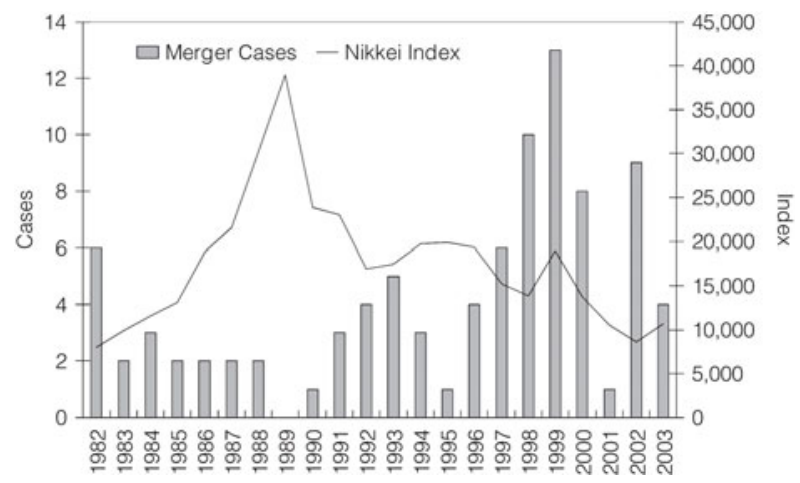

TABLE 1

Merger Characteristics by Subperiod

In Table 1, the sample consists of 91 mergers between bidder and target firms listed on the Tokyo Stock Exchange (TSE) for which the announcement date of the merger is between 1 January 1982 and 31 December 2003. A main bank is defined as a bank that is a firm's most important lender and belongs to the firm's largest 5 shareholders, as indicated in keiretsu no kenkyu for the year of the announcement. Bidder main bank and Target main bank refer to buying and selling firms that have a main bank relationship, and Common main bank refers to those cases where the buying and selling firms share the same main bank. We define firms as being in financial distress when interest expense exceeds operating income; the interest coverage ratio is lower than 1, in i) the last fiscal year prior to the merger, or ii) 2 of the 4 years before the merger. Interindustry and intraindustry mergers are determined based on the listing codes on the TSE.

\begin{tabular}{|c|c|c|c|c|c|}
\hline$\underline{\text { Merger Characteristics }}$ & All & $\underline{1980 s}$ & $\underline{1990 s}$ & Early 1990s & $\underline{\text { Late 1990s }}$ \\
\hline No. of mergers & 91 & 19 & 72 & 21 & 51 \\
\hline $\begin{array}{l}\text { Bidder main bank } \\
\text { Target main bank } \\
\text { Common main bank }\end{array}$ & $\begin{array}{l}65 \% \\
67 \% \\
31 \%\end{array}$ & $\begin{array}{l}53 \% \\
58 \% \\
29 \%\end{array}$ & $\begin{array}{l}68 \% \\
72 \% \\
31 \%\end{array}$ & $\begin{array}{l}95 \% \\
76 \% \\
52 \%\end{array}$ & $\begin{array}{l}57 \% \\
67 \% \\
22 \%\end{array}$ \\
\hline Same keiretsu & $52 \%$ & $26 \%$ & $58 \%$ & $62 \%$ & $57 \%$ \\
\hline Interindustry & $19 \%$ & $37 \%$ & $14 \%$ & $24 \%$ & $10 \%$ \\
\hline $\begin{array}{l}\text { Bidder distressed } \\
\text { Target distressed } \\
\text { Both distressed }\end{array}$ & $\begin{array}{l}35 \% \\
51 \% \\
27 \%\end{array}$ & $\begin{array}{l}58 \% \\
63 \% \\
47 \%\end{array}$ & $\begin{array}{l}29 \% \\
47 \% \\
22 \%\end{array}$ & $\begin{array}{l}33 \% \\
67 \% \\
29 \%\end{array}$ & $\begin{array}{l}27 \% \\
39 \% \\
20 \%\end{array}$ \\
\hline
\end{tabular}

a common main bank. Mergers in which the merging firms have a main bank are concentrated in the early 1990s; in this period more than $1 / 2$ of all mergers occur between firms with a common main bank. In the 1980s and late 1990s, mergers involving firms with a common main bank are $29 \%$ and $22 \%$ of all mergers in these periods.

It appears that the frequency of mergers involving firms in the same keiretsu more than doubles after the asset pricing bubble of the late 1980s imploded. Same keiretsu mergers represented $26 \%$ of all mergers in the 1980s but increased to $58 \%$ of all mergers in the 1990s. Again, this is consistent with the notion that member firms, likely at the behest of keiretsu main banks, step in to engineer rescue mergers when economic growth stagnates. 
Based on the NEEDS industry classification we investigate whether the mergers are within an industry (intraindustry), or whether they involve firms from different industries (interindustry). Whereas intraindustry mergers can be thought of as strategic and efficiency motivated, interindustry mergers are more likely motivated by hubris. In the 1980s interindustry mergers accounted for $37 \%$ of all mergers. This fraction declined to $24 \%$ in the early 1990 s and to $10 \%$ in the late 1990s. With the worsening economic outlook in the 1990s, the declining incidence of cross-industry mergers indicates that mergers during this latter period were driven primarily by strategic imperatives, and less so by managerial empire building or hubris considerations. ${ }^{7}$

We define financial distress following Hoshi et al. (1990) and select firms that experience a cash flow crisis: Firms are in financial distress when interest expense exceeds operating income, that is, when interest coverage ratio is less than 1 in the last fiscal year prior to the merger, or in 2 of the 4 years before the merger. Mergers involving a distressed bidder are most frequent in the 1980s, accounting for $58 \%$ of all mergers during this period. Mergers involving a financially distressed target peak in the early 1990s (67\% of all mergers). Mergers involving 2 distressed firms are most frequent in the 1980 s at $47 \%$. Overall, $1 / 3$ of the mergers involve a distressed bidder, and in $1 / 2$ of all merger cases a distressed target is involved. The percentage of mergers involving 2 distressed firms is highest in the 1980s and lowest in the late 1990s. These statistics are consistent with the idea that main banks, to the extent they can influence merger decisions, would benefit less if both merging parties were financially weak.

Table 2 combines our findings on financial distress of the merging firms and the presence of a common main bank by subperiod. We first note that across our entire sample, $42 \%(27 \%)$ of all mergers involve strong (weak) bidders and targets. The remaining $31 \%$ of mergers involve 1 weak and 1 strong firm. The bank power hypothesis makes 3 predictions here. First, the fraction of deals involving mergers of a weak and a strong firm ought to be higher when both merging firms share a common main bank. Second, this fraction ought to further increase when the economic situation worsens. And finally, main bank-instigated mergers are less likely to involve 2 weak firms.

Across the entire sampling period, we find that $40 \%$ of mergers involve 1 weak and 1 strong firm when a common main bank is involved. This fraction declines to $27 \%$ when there is no common main bank. In the early 1990 s this fraction peaked at $54 \%$ for mergers involving common main banks. This is consistent with our hypothesis that main bank interests are best served by combining a weak borrower with a strong borrower, and that the need to do so was more pressing in the difficult economic times of the early 1990s, spanning 1990 through 1996. In the late 1990s we see a similar pattern as well, though we note that many of the mergers in this period may have been driven by strategic motives.

Overall, 27\% of all mergers involve weak bidders and weak targets. Tellingly, this fraction declines to $18 \%$ of all mergers where a common main bank is

\footnotetext{
${ }^{7}$ Anecdotal evidence indicates that the trend toward strategic mergers, as opposed to cross-industry mergers, has strengthened in the years since our sample period ends (i.e., beyond 2004). Due to data limitations, we do not investigate whether this constitutes a trend.
} 


\section{TABLE 2}

Classification of Merging Firms by Financial Health

In Table 2, the sample consists of 91 mergers between bidder and target firms listed on the TSE for which the announcement date of the merger is between 1 January 1982 and 31 December 2003. A main bank is defined as a bank that is a firm's most important lender and belongs to the firm's largest 5 shareholders, as indicated in keiretsu no kenkyu for the year of the announcement. We define firms as being in financial distress when interest expense exceeds operating income; the interest coverage ratio is lower than 1, in i) the last fiscal year prior to the merger, or ii) 2 of the 4 years before the merger. Interindustry and intraindustry mergers are determined based on the listing codes on the TSE. A strong firm is not in financial distress; a weak firm is in financial distress.

\begin{tabular}{|c|c|c|c|c|c|c|c|}
\hline \multirow[b]{2}{*}{ Period } & \multirow[b]{2}{*}{$\underline{\text { Target }}$} & \multicolumn{2}{|c|}{ All } & \multicolumn{2}{|c|}{$\begin{array}{l}\text { Common } \\
\text { Main Bank }\end{array}$} & \multicolumn{2}{|c|}{$\begin{array}{c}\text { No Common } \\
\text { Main Bank }\end{array}$} \\
\hline & & $\begin{array}{l}\text { Strong } \\
\text { Bidder } \\
\end{array}$ & $\begin{array}{l}\text { Weak } \\
\text { Bidder } \\
\end{array}$ & $\begin{array}{l}\text { Strong } \\
\text { Bidder } \\
\end{array}$ & $\begin{array}{c}\text { Weak } \\
\text { Bidder } \\
\end{array}$ & $\begin{array}{l}\text { Strong } \\
\text { Bidder } \\
\end{array}$ & $\begin{array}{l}\text { Weak } \\
\text { Bidder } \\
\end{array}$ \\
\hline All & $\begin{array}{l}\text { Strong } \\
\text { Weak }\end{array}$ & $\begin{array}{l}42 \% \\
23 \%\end{array}$ & $\begin{array}{r}8 \% \\
27 \%\end{array}$ & $\begin{array}{l}43 \% \\
29 \%\end{array}$ & $\begin{array}{l}11 \% \\
18 \%\end{array}$ & $\begin{array}{l}41 \% \\
21 \%\end{array}$ & $\begin{array}{r}6 \% \\
32 \%\end{array}$ \\
\hline 1980s & $\begin{array}{l}\text { Strong } \\
\text { Weak }\end{array}$ & $\begin{array}{l}26 \% \\
16 \%\end{array}$ & $\begin{array}{l}11 \% \\
47 \%\end{array}$ & $\begin{array}{r}67 \% \\
0 \%\end{array}$ & $\begin{array}{l}17 \% \\
17 \%\end{array}$ & $\begin{array}{r}8 \% \\
23 \%\end{array}$ & $\begin{array}{r}8 \% \\
62 \%\end{array}$ \\
\hline Early 1990 s & $\begin{array}{l}\text { Strong } \\
\text { Weak }\end{array}$ & $\begin{array}{l}29 \% \\
38 \%\end{array}$ & $\begin{array}{r}5 \% \\
29 \%\end{array}$ & $\begin{array}{l}27 \% \\
45 \%\end{array}$ & $\begin{array}{r}9 \% \\
18 \%\end{array}$ & $\begin{array}{l}30 \% \\
30 \%\end{array}$ & $\begin{array}{r}0 \% \\
40 \%\end{array}$ \\
\hline Late 1990s & $\begin{array}{l}\text { Strong } \\
\text { Weak }\end{array}$ & $\begin{array}{l}53 \% \\
20 \%\end{array}$ & $\begin{array}{r}8 \% \\
20 \%\end{array}$ & $\begin{array}{l}45 \% \\
27 \%\end{array}$ & $\begin{array}{r}9 \% \\
18 \%\end{array}$ & $\begin{array}{l}55 \% \\
18 \%\end{array}$ & $\begin{array}{r}8 \% \\
20 \%\end{array}$ \\
\hline
\end{tabular}

involved and increases to $32 \%$ where no common main bank is found. These statistics are consistent with our hypothesis that banks have little to gain from a merger of 2 weak firms.

\section{Asset Characteristics and Credit Arrangement of Bidder and Target Firms}

Table 3 describes the accounting and market characteristics of the target and bidder firms in the sample. Target firms have a mean (median) value of book assets equal to 152 billion yen (51 billion yen). The corresponding mean (median) value of assets for bidders is 690 billion yen (200 billion yen). The mean size of target firms relative to bidders was $14 \%$ in the 1980 s, $28 \%$ in the early 1990 s, and $42 \%$ in the late 1990s. The increase in the size of the acquired firms is consistent with the increased emphasis on scale-motivated mergers in the 1990s, as opposed to the acquisition of unrelated assets in the 1980s.

Turning to the importance of the main bank, we find that main bank loans accounted for more than 5\% of the median target firm's debt in the 1980s and fell to $1 / 2$ of this fraction in the 1990s. A similar decline in the fraction of debt represented by main banks is found for bidder firms. The declining importance of main bank loans is consistent with anecdotal evidence on the status of main banks in Japan, and with the evidence in Arikawa and Miyajima (2007). Nevertheless, considerable variation remains in the role played by main banks across our sample, as is evident by examining the mean ratios for main bank debt to total debt. The mean values are considerably higher than the median values, suggesting a right-skewed distribution where some firms are far more reliant on main bank financing than the representative firm. The fraction of equity shares of the merging firms held by the main bank varies between $4 \%$ and $5 \%$. While this appears small, 


\section{TABLE 3}

Assets and Other Descriptive Statistics of Bidder and Target Firms

In Table 3, the sample consists of 91 mergers between Japanese bidder and target firms listed on the TSE for which the announcement date of the merger is between 1 January 1982 and 31 December 2003. Accounting data are derived from the NEEDS Tapes. Data on shareholders of the bidder and target firms are from the publication keiretsu no kenkyu. A main bank is defined as a bank that is a firm's most important lender and belongs to the firm's largest 5 shareholders, as indicated in keiretsu no kenkyu for the year of the announcement.

\begin{tabular}{|c|c|c|c|c|c|c|}
\hline \multirow[b]{2}{*}{ Variable } & \multicolumn{3}{|c|}{ Target } & \multicolumn{3}{|c|}{ Bidder } \\
\hline & $n$ & Mean & Median & $\underline{n}$ & Mean & Median \\
\hline \multicolumn{7}{|c|}{ Panel A. Total Assets (mln yen) } \\
\hline All & 91 & 151,609 & 51,448 & 91 & 690,302 & 199,709 \\
\hline $1980 \mathrm{~s}$ & 19 & 141,863 & 15,895 & 19 & 473,691 & 122,176 \\
\hline Early 1990s & 21 & 208,165 & 114,680 & 21 & $1,078,900$ & 701,222 \\
\hline Late 1990s & 51 & 131,952 & 55,933 & 51 & 610,989 & 152,572 \\
\hline \multicolumn{7}{|c|}{ Panel B. Total Assets Target/Total Assets Bidder } \\
\hline All & 91 & & & 91 & & 0.343 \\
\hline $1980 \mathrm{~s}$ & 19 & & & 19 & & 0.138 \\
\hline Early 1990s & 21 & & & 21 & & 0.278 \\
\hline Late 1990s & 51 & & & 51 & & 0.417 \\
\hline \multicolumn{7}{|c|}{ Panel C. Main Bank Loans/Debt } \\
\hline All & 63 & 0.073 & 0.030 & 59 & 0.045 & 0.011 \\
\hline $1980 \mathrm{~s}$ & 11 & 0.088 & 0.054 & 10 & 0.131 & 0.042 \\
\hline Early 1990s & 16 & 0.047 & 0.028 & 20 & 0.022 & 0.006 \\
\hline Late 1990s & 36 & 0.080 & 0.026 & 29 & 0.031 & 0.010 \\
\hline \multicolumn{7}{|c|}{ Panel D. Main Bank Shareholding (ownership \%) } \\
\hline All & 63 & 4.2 & 4.7 & 59 & 4.3 & 4.5 \\
\hline $1980 \mathrm{~s}$ & 11 & 5.3 & 4.8 & 10 & 5.3 & 5.1 \\
\hline Early 1990s & 16 & 4.5 & 4.8 & 20 & 3.8 & 4.0 \\
\hline Late 1990s & 36 & 3.7 & 4.3 & 29 & 4.2 & 4.5 \\
\hline \multicolumn{7}{|c|}{ Panel E. Common Financial Institution Shareholders (ownership \%) } \\
\hline All & 69 & 9.8 & 7.8 & 69 & 10.7 & 10.0 \\
\hline $1980 \mathrm{~s}$ & 15 & 11.6 & 8.9 & 15 & 12.9 & 13.9 \\
\hline Early 1990s & 20 & 11.8 & 10.3 & 20 & 11.8 & 11.7 \\
\hline Late 1990s & 34 & 7.8 & 7.1 & 34 & 9.0 & 7.8 \\
\hline
\end{tabular}

it should be noted that banks' ownership of corporations is capped at 5\% in Japan under ordinary circumstances as of $1987 .{ }^{8}$

Table 4 presents the return on assets (ROAs) of the bidder and target firms for the full sample period and by subperiod. For the full sample period, we find that the ROA for bidder and target firms declines slightly in the 3 years prior to the merger and picks up modestly in the 3rd year of the merger. In general, we note that target firm ROA tends to be lower than that of bidders, with the difference being largest in the early 1990s. Not surprisingly, combining a more profitable bidder with a less profitable target firm results in a decline in ROA following the merger. Performance in the 3-year period after the merger remains stable.

Looking at subperiods, it appears that profitability prior to the merger is highest in the 1980s, declines to its lowest value in the early 1990s, and rises a little in the late 1990s. This pattern is consistent with the general decline in profitability in the 1990s following the implosion of the asset bubble of the late 1980s.

\footnotetext{
${ }^{8}$ Prior to 1987 , banks were allowed to have $10 \%$ ownership of companies.
} 
TABLE 4

Return on Assets for Bidder and Target Firms

In Table 4, the sample consists of 91 mergers between Japanese bidder and target firms listed on the TSE for which the announcement date of the merger is between 1 January 1982 and 31 December 2003. Return on assets (ROA) is calculated as operating profits scaled by the book value of total assets. All accounting data are retrieved from the NEEDS Tapes. Year 0 refers to the fiscal year containing the merger. Other years are defined relative to year 0.

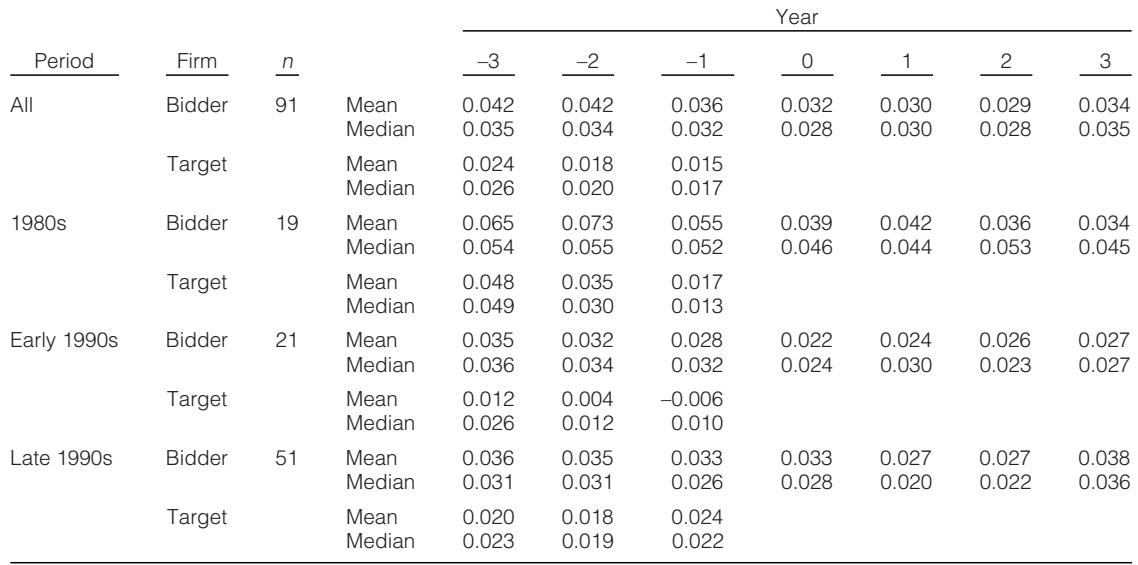

Overall, it does not appear that mergers in Japan are associated with significant improvements in ROA.

\section{Analysis of Bidder and Target Firm Returns}

Abnormal returns are computed beginning 50 days prior to and ending 50 days after the merger announcement using residuals from the market model. The market model parameters are estimated using daily data from 200 days to 50 days preceding the merger announcement using the Tokyo Stock Price Index (TOPIX) as the market index. ${ }^{9}$ The daily abnormal return is compounded over various time intervals to get the CAR. Table 5 gives CARs for several windows around the merger AD.

We find that the stock price of the target firm starts to rise as early as 50 days before the announcement. The abnormal return from day -50 to day 0 is $10.9 \%$, of which approximately $1 / 2$ occurs in the 5 days preceding the announcement of the merger ( $4.7 \%$ from day -5 to day 0 ). By the end of day +5 , the gain for target firms declines to $4.5 \%$ (cumulative gain from day -50 to day +5 ). By the end of day $+50,{ }^{10}$ target shares show an average cumulative gain of $5.6 \%$. For shorter windows (such as $[-2,+2]$ and $[-5,+5]$ ) the mean and median CARs for target firms are negative and insignificant.

\footnotetext{
${ }^{9}$ We repeat the calculation of abnormal returns with raw returns as well as an alternative valueweighted index and find materially similar results. These are not tabulated in order to conserve space.

${ }^{10}$ We looked for merger completions during the first 50 days following the announcement and found that the earliest completion date is 56 days following the merger. Thus the statistics reported here are not affected by target firms dropping out of the sample in the return windows.
} 


\section{TABLE 5}

CARs for Japanese Target and Bidder Firms in 1982-2003

\begin{tabular}{|c|c|c|c|c|}
\hline \multirow[b]{2}{*}{ Interval } & \multicolumn{2}{|c|}{ Target CAR } & \multicolumn{2}{|c|}{ Bidder CAR } \\
\hline & Mean & Median & Mean & Median \\
\hline$[-50,0]$ & $\begin{array}{c}0.109 \\
(0.000)\end{array}$ & $\begin{array}{c}0.098 \\
(0.001)\end{array}$ & $\begin{array}{c}0.039 \\
(0.034)\end{array}$ & $\begin{array}{c}0.014 \\
(0.098)\end{array}$ \\
\hline$[-5,0]$ & $\begin{array}{c}0.047 \\
(0.000)\end{array}$ & $\begin{array}{c}0.031 \\
(0.001)\end{array}$ & $\begin{array}{c}0.018 \\
(0.023)\end{array}$ & $\begin{array}{c}0.016 \\
(0.044)\end{array}$ \\
\hline$[-2,0]$ & $\begin{array}{c}0.024 \\
(0.031)\end{array}$ & $\begin{array}{c}0.008 \\
(0.036)\end{array}$ & $\begin{array}{c}0.011 \\
(0.074)\end{array}$ & $\begin{array}{c}0.006 \\
(0.058)\end{array}$ \\
\hline$[-1,0]$ & $\begin{array}{c}0.014 \\
(0.145)\end{array}$ & $\begin{array}{c}0.002 \\
(0.115)\end{array}$ & $\begin{array}{c}0.004 \\
(0.515)\end{array}$ & $\begin{array}{c}0.002 \\
(0.554)\end{array}$ \\
\hline$[-1,+1]$ & $\begin{array}{c}-0.010 \\
(0.466)\end{array}$ & $\begin{array}{c}0.000 \\
(0.446)\end{array}$ & $\begin{array}{c}-0.012 \\
(0.110)\end{array}$ & $\begin{array}{c}-0.012 \\
(0.087)\end{array}$ \\
\hline$[0,+2]$ & $\begin{array}{c}-0.037 \\
(0.039)\end{array}$ & $\begin{array}{c}-0.041 \\
(0.010)\end{array}$ & $\begin{array}{c}-0.013 \\
(0.084)\end{array}$ & $\begin{array}{c}-0.011 \\
(0.033)\end{array}$ \\
\hline$[0,+5]$ & $\begin{array}{c}-0.064 \\
(0.003)\end{array}$ & $\begin{array}{c}-0.066 \\
(0.001)\end{array}$ & $\begin{array}{c}-0.020 \\
(0.031)\end{array}$ & $\begin{array}{c}-0.022 \\
(0.020)\end{array}$ \\
\hline$[0,+50]$ & $\begin{array}{c}-0.046 \\
(0.063)\end{array}$ & $\begin{array}{c}-0.031 \\
(0.058)\end{array}$ & $\begin{array}{c}-0.017 \\
(0.315)\end{array}$ & $\begin{array}{c}-0.019 \\
(0.194)\end{array}$ \\
\hline$[-2,+2]$ & $\begin{array}{c}-0.020 \\
(0.260)\end{array}$ & $\begin{array}{c}-0.007 \\
(0.153)\end{array}$ & $\begin{array}{c}-0.006 \\
(0.503)\end{array}$ & $\begin{array}{c}-0.006 \\
(0.293)\end{array}$ \\
\hline$[-5,+5]$ & $\begin{array}{c}-0.024 \\
(0.264)\end{array}$ & $\begin{array}{c}-0.034 \\
(0.286)\end{array}$ & $\begin{array}{c}-0.006 \\
(0.566)\end{array}$ & $\begin{array}{c}-0.007 \\
(0.432)\end{array}$ \\
\hline$[-50,+50]$ & $\begin{array}{c}0.056 \\
(0.074)\end{array}$ & $\begin{array}{c}0.081 \\
(0.122)\end{array}$ & $\begin{array}{c}0.019 \\
(0.406)\end{array}$ & $\begin{array}{c}-0.009 \\
(0.786)\end{array}$ \\
\hline
\end{tabular}

Bidder firms in Japan appear to enjoy positive gains in the period leading up to the announcement of the merger. The bidder CAR from day -50 to day 0 is $3.9 \%$. Immediately after the merger announcement, the bidder share price falls (as was the case with the target). The cumulative return from day -50 to day +5 is $1.9 \%$ for the bidder, identical to that of the target firm during the same interval. There appears to be no recovery in bidder share prices in the following days. The cumulative bidder return from day +5 to day +50 is insignificant.

A puzzling result is the reversal of CARs over short windows surrounding the merger announcement for both target as well as bidder firms. Specifically, we find that while prices rise in the 5-, 2-, and 1-day windows prior to the merger announcement, this price rise is largely reversed in the 5-, 2-, and 1-day intervals following the announcement, rendering CARs over the event periods $[-5,+5]$, $[-2,+2]$, and $[-1,+1]$ statistically insignificant. Canceled mergers are very rare, in fact nonexistent in our sample, and they cannot explain this pattern.

Next we examine how characteristics of the merging firms influence the abnormal returns for the period $[-1,+1]$ (Tables 6 and 7). In particular, we are interested in examining whether financial leverage and shareholder affiliation affect value creation surrounding the merger announcements. We measure bank leverage as the value of total loans divided by the book value of assets and find that bidder firms with a ratio above the median have an average CAR $[-1,+1]$ of 
$-2.4 \%$ and a median CAR of $-1.6 \%$; however, these CARs are not significantly different from those of firms with leverage below the median. In general leverage does not appear to affect AD CARs.

TABLE 6

CARs for Bidder and Target Firms by Merging Firm Characteristics

In Table 6, the sample consists of 91 mergers between Japanese bidder and target firms listed on the TSE for which the AD of the merger is between 1 January 1982 and 31 December 2003. Information was collected on all firms that were delisted from TSE during the sample period. Next, it was investigated whether the delisted firms were engaged in a merger by investigating all press articles related to mergers in the period from 1982 to 2003. The initial AD (i.e., the 1st day on which the information related to the announcement was public before the end of the trading day) is defined as the day that the merger announcement appears in the press for the 1st time. The press articles from the Nihon Keizai Shimbun [Japan Economic Journal], Nikkei Sangyo Shimbun [Industrial Journal], Nikkei Ryutuu Shimbun [Distribution Journal], and Nikkei Kinyuu Shimbun [Finance Journal] are investigated. In parentheses below the mean and median, the $p$-values for, respectively, the $t$-tests and sign-rank tests are reported.

\begin{tabular}{|c|c|c|c|c|c|c|c|c|c|}
\hline \multirow[b]{2}{*}{ Merger Characteristics } & \multirow[b]{2}{*}{$n$} & \multicolumn{4}{|c|}{$\begin{array}{c}\text { Target } \\
\text { CAR }[-1,+1]\end{array}$} & \multicolumn{4}{|c|}{$\begin{array}{c}\text { Bidder } \\
\text { CAR }[-1,+1] \\
\end{array}$} \\
\hline & & Mean & Median & $t$-Test & Wilcoxon & Mean & Median & $t$-Test & Wilcoxon \\
\hline All & 91 & $\begin{array}{l}-0.010 \\
(0.466)\end{array}$ & $\begin{array}{c}0.000 \\
(0.446)\end{array}$ & & & $\begin{array}{l}-0.012 \\
(0.110)\end{array}$ & $\begin{array}{l}-0.012 \\
(0.087)\end{array}$ & & \\
\hline $\begin{array}{l}\text { Total bank loan ratio } \\
\text { above sample median }\end{array}$ & 46 & $\begin{array}{c}-0.017 \\
(0.259)\end{array}$ & $\begin{array}{c}0.000 \\
(0.368)\end{array}$ & $\begin{array}{c}0.483 \\
(0.630)\end{array}$ & & $\begin{array}{l}-0.024 \\
(0.035)\end{array}$ & $\begin{array}{l}-0.016 \\
(0.033)\end{array}$ & $\begin{array}{c}1.606 \\
(0.112)\end{array}$ & \\
\hline $\begin{array}{l}\text { Total bank loan ratio } \\
\text { below sample median }\end{array}$ & 45 & $\begin{array}{l}-0.003 \\
(0.888)\end{array}$ & $\begin{array}{c}0.000 \\
(0.803)\end{array}$ & & $\begin{array}{c}0.373 \\
(0.709)\end{array}$ & $\begin{array}{c}0.000 \\
(0.998)\end{array}$ & $\begin{array}{c}0.000 \\
(0.804)\end{array}$ & & $\begin{array}{c}1.353 \\
(0.176)\end{array}$ \\
\hline $\begin{array}{l}\text { Bidder and target have } \\
\text { common shareholder }\end{array}$ & 28 & $\begin{array}{c}0.010 \\
(0.691)\end{array}$ & $\begin{array}{c}0.003 \\
(0.747)\end{array}$ & $\begin{array}{c}0.971 \\
(0.334)\end{array}$ & & $\begin{array}{l}-0.007 \\
(0.637)\end{array}$ & $\begin{array}{c}0.001 \\
(0.542)\end{array}$ & $\begin{array}{c}0.536 \\
(0.595)\end{array}$ & \\
\hline $\begin{array}{l}\text { Bidder and target do not } \\
\text { have common } \\
\text { shareholder }\end{array}$ & 63 & $\begin{array}{l}-0.019 \\
(0.255)\end{array}$ & $\begin{array}{l}-0.001 \\
(0.249)\end{array}$ & & $\begin{array}{c}0.989 \\
(0.323)\end{array}$ & $\begin{array}{c}-0.014 \\
(0.101)\end{array}$ & $\begin{array}{l}-0.013 \\
(0.077)\end{array}$ & & $\begin{array}{c}0.557 \\
(0.577)\end{array}$ \\
\hline $\begin{array}{l}\text { Common shareholder } \\
\text { over } 20 \%\end{array}$ & 16 & $\begin{array}{c}0.006 \\
(0.819)\end{array}$ & $\begin{array}{c}0.009 \\
(0.755)\end{array}$ & $\begin{array}{c}0.534 \\
(0.594)\end{array}$ & & $\begin{array}{c}0.010 \\
(0.481)\end{array}$ & $\begin{array}{c}0.012 \\
(0.423)\end{array}$ & $\begin{array}{c}1.359 \\
(0.178)\end{array}$ & \\
\hline $\begin{array}{l}\text { No common shareholder } \\
\text { over } 20 \%\end{array}$ & 75 & $\begin{array}{c}-0.014 \\
(0.397)\end{array}$ & $\begin{array}{c}0.000 \\
(0.340)\end{array}$ & & $\begin{array}{c}0.751 \\
(0.453)\end{array}$ & $\begin{array}{l}-0.017 \\
(0.054)\end{array}$ & $\begin{array}{l}-0.014 \\
(0.021)\end{array}$ & & $\begin{array}{c}1.632 \\
(0.103)\end{array}$ \\
\hline $\begin{array}{l}\text { Large corporate } \\
\text { shareholder in target or } \\
\text { bidder }\end{array}$ & 27 & $\begin{array}{c}0.021 \\
(0.241)\end{array}$ & $\begin{array}{c}0.000 \\
(0.294)\end{array}$ & $\begin{array}{c}1.481 \\
(0.142)\end{array}$ & & $\begin{array}{l}-0.017 \\
(0.324)\end{array}$ & $\begin{array}{c}-0.022 \\
(0.047)\end{array}$ & $\begin{array}{c}0.404 \\
(0.688)\end{array}$ & \\
\hline $\begin{array}{l}\text { No large corporate } \\
\text { shareholder in target } \\
\text { or bidder }\end{array}$ & 64 & $\begin{array}{l}-0.023 \\
(0.200)\end{array}$ & $\begin{array}{l}-0.001 \\
(0.134)\end{array}$ & & $\begin{array}{c}1.499 \\
(0.134)\end{array}$ & $\begin{array}{l}-0.010 \\
(0.216)\end{array}$ & $\begin{array}{c}0.002 \\
(0.549)\end{array}$ & & $\begin{array}{c}1.738 \\
(0.082)\end{array}$ \\
\hline Member of same keiretsu & 47 & $\begin{array}{l}-0.026 \\
(0.156)\end{array}$ & $\begin{array}{c}0.000 \\
(0.296)\end{array}$ & $\begin{array}{c}1.196 \\
(0.235)\end{array}$ & & $\begin{array}{l}-0.018 \\
(0.085)\end{array}$ & $\begin{array}{l}-0.015 \\
(0.214)\end{array}$ & $\begin{array}{c}0.816 \\
(0.417)\end{array}$ & \\
\hline $\begin{array}{l}\text { Not member of same } \\
\text { keiretsu }\end{array}$ & 44 & $\begin{array}{c}0.007 \\
(0.743)\end{array}$ & $\begin{array}{c}0.000 \\
(0.940)\end{array}$ & & $\begin{array}{c}0.647 \\
(0.517)\end{array}$ & $\begin{array}{c}-0.006 \\
(0.604)\end{array}$ & $\begin{array}{c}-0.011 \\
(0.259)\end{array}$ & & $\begin{array}{c}0.171 \\
(0.864)\end{array}$ \\
\hline Intraindustry merger & 74 & $\begin{array}{c}0.003 \\
(0.842)\end{array}$ & $\begin{array}{c}0.001 \\
(0.739)\end{array}$ & $\begin{array}{c}2.035 \\
(0.045)\end{array}$ & & $\begin{array}{c}-0.011 \\
(0.204)\end{array}$ & $\begin{array}{c}-0.011 \\
(0.156)\end{array}$ & $\begin{array}{c}0.308 \\
(0.759)\end{array}$ & \\
\hline Interindustry merger & 17 & $\begin{array}{c}-0.068 \\
(0.018)\end{array}$ & $\begin{array}{c}-0.047 \\
(0.011)\end{array}$ & & $\begin{array}{c}2.449 \\
(0.014)\end{array}$ & $\begin{array}{c}-0.017 \\
(0.283)\end{array}$ & $\begin{array}{c}-0.018 \\
(0.394)\end{array}$ & & $\begin{array}{c}0.270 \\
(0.787)\end{array}$ \\
\hline
\end{tabular}

The presence of a common shareholder in the target and bidder firms does not have an important influence over CARs vis-à-vis firms where there are no common shareholders. The presence of a large corporate shareholder has a small negative influence on the bidder's abnormal returns; the median CAR of bidder firms with a large corporate shareholder is significantly negative and distinguishable from the median for firms that do not have a large corporate shareholder (however, the corresponding mean difference is not significant). Keiretsu affiliation or common blockholders (defined as owning $>20 \%$ of the firm) do not appear to have a significant impact on CARs for target and bidder firms. Overall it does not appear that shareholder affiliation affects merger wealth effects in our sample. 


\section{TABLE 7}

CARs for Japanese Bidder and Target Firms by Period

In Table 7, the sample consists of 91 mergers between Japanese bidder and target firms listed on the TSE for which the AD of the merger is between 1 January 1982 and 31 December 2003. Information was collected on all firms that were delisted from TSE during the sample period. Next, it was investigated whether the delisted firms were engaged in a merger by investigating all press articles related to mergers in the period from 1982 to 2003 . The initial AD (i.e., the 1st day on which the information related to the announcement was public before the end of the trading day) is defined as the day that the merger announcement appears in the press for the 1st time. The press articles from the Nihon Keizai Shimbun [Japan Economic Journal], Nikkei Sangyo Shimbun [Industrial Journal], Nikkei Ryutuu Shimbun [Distribution Journal], and Nikkei Kinyuu Shimbun [Finance Journal] are investigated. In parentheses below the mean and median, the p-values for, respectively, thet-tests and sign-rank tests are reported.

\begin{tabular}{|c|c|c|c|c|c|c|c|c|c|}
\hline \multirow[b]{2}{*}{ Period } & \multirow[b]{2}{*}{$\underline{n}$} & \multicolumn{4}{|c|}{ Target CAR $[-1,+1]$} & \multicolumn{4}{|c|}{ Bidder CAR $[-1,+1]$} \\
\hline & & Mean & Median & $t$-Test & Wilcoxon & Mean & Median & $t$-Test & Wilcoxon \\
\hline $1980 s$ & 19 & $\begin{array}{c}-0.046 \\
(0.161)\end{array}$ & $\begin{array}{c}-0.004 \\
(0.207)\end{array}$ & & & $\begin{array}{c}-0.016 \\
(0.266)\end{array}$ & $\begin{array}{c}0.003 \\
(0.457)\end{array}$ & & \\
\hline Early 1990s (1990-1996) & 21 & $\begin{array}{c}-0.022 \\
(0.271)\end{array}$ & $\begin{array}{c}0.000 \\
(0.486)\end{array}$ & & & $\begin{array}{c}-0.031 \\
(0.000)\end{array}$ & $\begin{array}{c}-0.039 \\
(0.001)\end{array}$ & & \\
\hline Late 1990s (1997-2003) & 51 & $\begin{array}{c}0.008 \\
(0.682)\end{array}$ & $\begin{array}{c}0.000 \\
(0.796)\end{array}$ & & & $\begin{array}{c}-0.003 \\
(0.809)\end{array}$ & $\begin{array}{c}0.000 \\
(0.921)\end{array}$ & & \\
\hline Comparison 1980s-early 1990s & & & & $\begin{array}{c}0.646 \\
(0.522)\end{array}$ & $\begin{array}{c}0.826 \\
(0.409)\end{array}$ & & & $\begin{array}{c}1.027 \\
(0.311)\end{array}$ & $\begin{array}{c}1.273 \\
(0.203)\end{array}$ \\
\hline Comparison early 1990s-late 1990s & & & & $\begin{array}{c}0.909 \\
(0.367)\end{array}$ & $\begin{array}{c}0.830 \\
(0.407)\end{array}$ & & & $\begin{array}{c}1.468 \\
(0.147)\end{array}$ & $\begin{array}{c}2.416 \\
(0.016)\end{array}$ \\
\hline Comparison 1980s-late 1990s & & & & $\begin{array}{c}1.426 \\
(0.158)\end{array}$ & $\begin{array}{c}1.347 \\
(0.178)\end{array}$ & & & $\begin{array}{c}0.604 \\
(0.548)\end{array}$ & $\begin{array}{c}0.806 \\
(0.421)\end{array}$ \\
\hline
\end{tabular}

Finally, we examine wealth effects for unrelated (interindustry) versus scale (intraindustry) mergers and find that CARs for unrelated mergers are significantly negative for target firms, though not for bidder firms. The mean is negative at $-6.8 \%$ and the median at $-4.7 \%$, both statistically different from the CARs of target firms in same-industry mergers. Bidder returns are not influenced by whether the target is in the same industry or not.

Table 7 indicates that target firms' CARs are not significantly different from 0 in any of the subperiods examined here. The bidder CAR has a mean of $-3.1 \%$ and median of $-3.9 \%$ in the early $1990 \mathrm{~s}$; both are significant at the $1 \%$ level. In the other 2 subperiods the bidder returns are not significantly different from 0 . Comparing bidder CARs from the early 1990s with those from the late 1990s, we find that only the median values are statistically different at the $5 \%$ significance level. We will next turn to the influence of financial distress on abnormal returns surrounding merger announcements.

\section{Financial Distress and Merger Returns}

Table 8 presents the results of our tests that examine the influence of financial distress on abnormal returns; we look into financial distress for the target firm, the bidder firm, and both merging firms.

Target CAR. Table 8 shows that the financial condition of the target firm and/or the bidder firm does not have any significant influence over the CARs of target firms. The CAR for target firms is not significantly different from 0 whether target firms are in financial distress or not. A similar pattern is visible in case the bidder firm is in financial distress or both merging firms are in financial distress. 
TABLE 8

CARs for Japanese Bidder and Target Firms Categorized by Financial Distress

In Table 8, the sample consists of 91 mergers between Japanese bidder and target firms listed on the TSE for which the AD of the merger is between 1 January 1982 and 31 December 2003. Information was collected on all firms that were delisted from TSE during the sample period. Next, it was investigated whether the delisted firms were engaged in a merger by investigating all press articles related to mergers in the period from 1982 to 2003. The initial AD (i.e., the 1st day on which the information related to the announcement was public before the end of the trading day) is defined as the day that the merger announcement appears in the press for the 1st time. The press articles from the Nihon Keizai Shimbun [Japan Economic Journal], Nikkei Sangyo Shimbun [Industrial Journal], Nikkei Ryutuu Shimbun [Distribution Journal], and Nikkei Kinyuu Shimbun [Finance Journal] are investigated. In parentheses below the mean and median, the $p$-values for, respectively, the $t$-tests and sign-rank tests are reported.

\begin{tabular}{|c|c|c|c|c|c|c|c|c|c|}
\hline \multirow[b]{2}{*}{ Merging Firm Type } & \multirow[b]{2}{*}{$n$} & \multicolumn{4}{|c|}{ Target CAR $[-1,+1]$} & \multicolumn{4}{|c|}{ Bidder CAR $[-1,+1]$} \\
\hline & & Mean & Median & $t$-Test & $\underline{\text { Wilcoxon }}$ & Mean & Median & $t$-Test & Wilcoxon \\
\hline Target in distress & 46 & $\begin{array}{l}-0.018 \\
(0.299)\end{array}$ & $\begin{array}{c}-0.001 \\
(0.296)\end{array}$ & $\begin{array}{c}0.593 \\
(0.555)\end{array}$ & & $\begin{array}{l}-0.030 \\
(0.002)\end{array}$ & $\begin{array}{l}-0.029 \\
(0.001)\end{array}$ & $\begin{array}{c}2.474 \\
(0.015)\end{array}$ & \\
\hline Target not in distress & 45 & $\begin{array}{c}-0.002 \\
(0.934)\end{array}$ & $\begin{array}{c}0.000 \\
(0.990)\end{array}$ & & $\begin{array}{c}0.635 \\
(0.525)\end{array}$ & $\begin{array}{c}0.006 \\
(0.589)\end{array}$ & $\begin{array}{c}0.009 \\
(0.245)\end{array}$ & & $\begin{array}{l}3.401 \\
(0.001)\end{array}$ \\
\hline Bidder in distress & 32 & $\begin{array}{l}-0.023 \\
(0.309)\end{array}$ & $\begin{array}{l}-0.001 \\
(0.332)\end{array}$ & $\begin{array}{c}0.693 \\
(0.490)\end{array}$ & & $\begin{array}{l}-0.024 \\
(0.033)\end{array}$ & $\begin{array}{l}-0.025 \\
(0.060)\end{array}$ & $\begin{array}{c}1.206 \\
(0.231)\end{array}$ & \\
\hline Bidder not in distress & 59 & $\begin{array}{c}-0.003 \\
(0.863)\end{array}$ & $\begin{array}{c}0.000 \\
(0.890)\end{array}$ & & $\begin{array}{c}0.748 \\
(0.454)\end{array}$ & $\begin{array}{c}-0.005 \\
(0.583)\end{array}$ & $\begin{array}{c}0.000 \\
(0.496)\end{array}$ & & $\begin{array}{l}1.425 \\
(0.154)\end{array}$ \\
\hline $\begin{array}{l}\text { Target and bidder } \\
\text { in distress }\end{array}$ & 25 & $\begin{array}{c}-0.009 \\
(0.729)\end{array}$ & $\begin{array}{c}0.000 \\
(0.809)\end{array}$ & $\begin{array}{c}0.029 \\
(0.977)\end{array}$ & & $\begin{array}{c}-0.030 \\
(0.016)\end{array}$ & $\begin{array}{l}-0.029 \\
(0.021)\end{array}$ & $\begin{array}{c}1.482 \\
(0.142)\end{array}$ & \\
\hline $\begin{array}{l}\text { Target and bidder not } \\
\text { in distress }\end{array}$ & 66 & $\begin{array}{l}-0.010 \\
(0.524)\end{array}$ & $\begin{array}{c}0.000 \\
(0.520)\end{array}$ & & $\begin{array}{c}0.049 \\
(0.961)\end{array}$ & $\begin{array}{l}-0.005 \\
(0.569)\end{array}$ & $\begin{array}{c}0.000 \\
(0.591)\end{array}$ & & $\begin{array}{l}1.872 \\
(0.061)\end{array}$ \\
\hline
\end{tabular}

Bidder CAR. The abnormal returns of bidder firms are significantly negative for all merger cases in which a firm in financial distress is involved. In mergers in which the target or the bidder or both firms are in financial distress, the mean and median CARs of bidder firms are $-3.0 \%$ and $-2.9 \%$, respectively. These are significantly lower than bidder returns where the target or bidder or both are not in financial distress. When the bidder firm itself is in financial distress, the mean return is $-2.4 \%$ and the median is $-2.5 \%$. However, these are not statistically different from CARs for healthy bidders ( $p$-value of difference $=0.15$ ).

Overall, a significant negative impact on the returns of bidder firms is found in mergers involving a target in financial distress. To examine these results in more detail, we condition the results on whether the target and bidder firms have a common main bank. In particular, we are interested in knowing whether a common main bank is associated with lower $\mathrm{AD}$ returns for the bidder when the target or the bidder firm is in financial distress. Results are presented in Table 9.

First we look at cases where neither the target nor the bidder firm is in financial distress. We find that mean returns for both bidder and target firms are significantly higher when the merging firms do not share a common main bank relative to returns for bidder and target firms with a common main bank. Indeed, the mean $\mathrm{AD}$ return for target and bidder firms is not statistically significant when the merging firms have a common main bank. However, the median test for differences between the 2 subsamples is not significant.

Next we examine cases where either the target firm or the bidder firm, but not both, are in financial distress. These are cases where the bank power hypothesis predicts that mergers will be motivated by a desire to protect the creditor's collateral, rather than any shareholder considerations. We find that the AD returns for 


\section{TABLE 9}

CARs for Japanese Bidder and Target Firms by Main Bank Involvement

In Table 9, the sample consists of 91 mergers between Japanese bidder and target firms listed on the TSE for which the AD of the merger is between 1 January 1982 and 31 December 2003. Information was collected on all firms that were delisted from TSE during the sample period. Next, it was investigated whether the delisted firms were engaged in a merger by investigating all press articles related to mergers in the period from 1982 to 2003 . The initial AD (i.e., the 1 st day on which the information related to the announcement was public before the end of the trading day) is defined as the day that the merger announcement appears in the press for the 1st time. The press articles from the Nihon Keizai Shimbun [Japan Economic Journal], Nikkei Sangyo Shimbun [Industrial Journal], Nikkei Ryutuu Shimbun [Distribution Journal], and Nikkei Kinyuu Shimbun [Finance Journal] are investigated. In parentheses below the mean and median, the p-values for, respectively, the $t$-tests and sign-rank tests are reported.

\begin{tabular}{|c|c|c|c|c|c|c|c|c|c|}
\hline \multirow[b]{2}{*}{ Merging Firm Type } & \multirow[b]{2}{*}{$\underline{n}$} & \multicolumn{4}{|c|}{ Target CAR $[-1,+1]$} & \multicolumn{4}{|c|}{ Bidder CAR $[-1,+1]$} \\
\hline & & Mean & Median & $t$-Test & $\underline{\text { Wilcoxon }}$ & Mean & Median & $t$-Test & $\underline{\text { Wilcoxon }}$ \\
\hline \multicolumn{10}{|c|}{ Panel A. Target and Bidder Not in Distress } \\
\hline Common main bank & 12 & $\begin{array}{c}-0.068 \\
(0.219)\end{array}$ & $\begin{array}{c}-0.041 \\
(0.774)\end{array}$ & $\begin{array}{l}2.311 \\
(0.027)\end{array}$ & & $\begin{array}{c}-0.028 \\
(0.329)\end{array}$ & $\begin{array}{c}-0.003 \\
(1.000)\end{array}$ & $\begin{array}{c}2.089 \\
(0.044)\end{array}$ & \\
\hline No common main bank & 26 & $\begin{array}{c}0.048 \\
(0.060)\end{array}$ & $\begin{array}{c}0.024 \\
(0.308)\end{array}$ & & $\begin{array}{c}1.727 \\
(0.084)\end{array}$ & $\begin{array}{c}0.025 \\
(0.045)\end{array}$ & $\begin{array}{c}0.009 \\
(0.093)\end{array}$ & & $\begin{array}{c}1.539 \\
(0.124)\end{array}$ \\
\hline \multicolumn{10}{|c|}{ Panel B. Target or Bidder in Distress } \\
\hline Common main bank & 11 & $\begin{array}{c}-0.074 \\
(0.018)\end{array}$ & $\begin{array}{c}-0.082 \\
(0.344)\end{array}$ & $\begin{array}{c}1.606 \\
(0.121)\end{array}$ & & $\begin{array}{c}-0.059 \\
(0.005)\end{array}$ & $\begin{array}{c}-0.066 \\
(0.065)\end{array}$ & $\begin{array}{c}2.343 \\
(0.027)\end{array}$ & \\
\hline No common main bank & 17 & $\begin{array}{c}-0.017 \\
(0.452)\end{array}$ & $\begin{array}{c}0.000 \\
(0.791)\end{array}$ & & $\begin{array}{c}1.460 \\
(0.144)\end{array}$ & $\begin{array}{c}0.000 \\
(0.997)\end{array}$ & $\begin{array}{c}-0.013 \\
(1.000)\end{array}$ & & $\begin{array}{c}1.999 \\
(0.046)\end{array}$ \\
\hline \multicolumn{10}{|c|}{ Panel C. Target and Bidder in Distress } \\
\hline Common main bank & 5 & $\begin{array}{c}-0.058 \\
(0.456)\end{array}$ & $\begin{array}{c}0.000 \\
(1.000)\end{array}$ & $\begin{array}{c}0.887 \\
(0.384)\end{array}$ & & $\begin{array}{c}-0.046 \\
(0.283)\end{array}$ & $\begin{array}{c}-0.029 \\
(0.375)\end{array}$ & $\begin{array}{c}0.683 \\
(0.501)\end{array}$ & \\
\hline No common main bank & 20 & $\begin{array}{c}0.003 \\
(0.932)\end{array}$ & $\begin{array}{c}-0.001 \\
(1.000)\end{array}$ & & $\begin{array}{c}0.340 \\
(0.734)\end{array}$ & $\begin{array}{c}-0.026 \\
(0.038)\end{array}$ & $\begin{array}{c}-0.026 \\
(0.115)\end{array}$ & & $\begin{array}{c}0.272 \\
(0.786)\end{array}$ \\
\hline
\end{tabular}

both target and bidder firms is significantly negative ( $-7.4 \%$ for targets, and $-5.9 \%$ for bidders) when they share a common main bank, and statistically insignificant when they do not. The difference in bidders' abnormal returns for the 2 cases, common main bank versus no common main bank, is statistically significant for both the mean and the median difference tests. When we examine abnormal returns for cases where both the bidder and the target firms are in financial distress, we do not find any significant results. Recall that in these cases, the main bank has little to gain from the merger.

In Table 10 we repeat the above tests using ordinary least squares (OLS) regressions. The regressions take the following form:

$$
\mathrm{ADRET}_{i}=a+b \cdot \mathrm{COMMON} \_\mathrm{MB}_{i}+c \cdot \mathrm{ROA}_{i}+e_{i},
$$

where ADRET is the announcement return spanning days $[-1,+1]$, COMMON $\mathrm{MB}$ is a dummy variable $=1$ when the target and bidder firms share a common main bank, and ROA is the premerger return on assets (the ratio of operating income to book assets) measured as of the last fiscal year-end value prior to the merger announcement. The regression is estimated separately for the target firms, the bidder firms, and for both firms combined (by adding the announcement returns and operating income for both firms).

Our main results in Table 10 confirm our earlier univariate comparisons. That is, we find that announcement returns for bidder as well as target firms are 
TABLE 10

Announcement Return Regressions

\begin{tabular}{|c|c|c|c|}
\hline Explanatory Variables & All & $1980 \mathrm{~s}$ & 1990s \\
\hline \multicolumn{4}{|c|}{ Panel A. Dependent Variable: Total Return } \\
\hline Intercept & $\begin{array}{c}-0.034 \\
(0.880)\end{array}$ & $\begin{array}{c}-0.111 \\
(0.030)\end{array}$ & $\begin{array}{c}0.030 \\
(0.230)\end{array}$ \\
\hline Common main bank & $\begin{array}{c}-0.132 \\
(0.000)\end{array}$ & $\begin{array}{c}-0.008 \\
(0.920)\end{array}$ & $\begin{array}{c}-0.174 \\
(0.000)\end{array}$ \\
\hline Premerger $\mathrm{ROA}$ & $\begin{array}{c}0.425 \\
(0.040)\end{array}$ & $\begin{array}{c}0.716 \\
(0.070)\end{array}$ & $\begin{array}{c}0.239 \\
(0.320)\end{array}$ \\
\hline Adjusted $R^{2}$ & 0.144 & 0.108 & 0.206 \\
\hline \multicolumn{4}{|c|}{ Panel B. Dependent Variable: Bidder Return } \\
\hline Intercept & $\begin{array}{c}-0.006 \\
(0.600)\end{array}$ & $\begin{array}{c}-0.055 \\
(0.020)\end{array}$ & $\begin{array}{c}0.003 \\
(0.780)\end{array}$ \\
\hline Common main bank & $\begin{array}{c}-0.046 \\
(0.000)\end{array}$ & $\begin{array}{c}0.056 \\
(0.040)\end{array}$ & $\begin{array}{c}-0.074 \\
(0.000)\end{array}$ \\
\hline Premerger $\mathrm{ROA}$ & $\begin{array}{c}0.222 \\
(0.280)\end{array}$ & $\begin{array}{c}0.371 \\
(0.200)\end{array}$ & $\begin{array}{c}0.263 \\
(0.320)\end{array}$ \\
\hline Adjusted $R^{2}$ & 0.080 & 0.205 & 0.199 \\
\hline \multicolumn{4}{|c|}{ Panel C. Dependent Variable: Target Return } \\
\hline Intercept & $\begin{array}{c}0.012 \\
(0.460)\end{array}$ & $\begin{array}{c}-0.036 \\
(0.350)\end{array}$ & $\begin{array}{c}0.031 \\
(0.090)\end{array}$ \\
\hline Common main bank & $\begin{array}{c}-0.085 \\
(0.000)\end{array}$ & $\begin{array}{c}-0.072 \\
(0.350)\end{array}$ & $\begin{array}{c}-0.104 \\
(0.000)\end{array}$ \\
\hline Premerger $\mathrm{ROA}$ & $\begin{array}{c}0.262 \\
(0.190)\end{array}$ & $\begin{array}{c}0.738 \\
(0.090)\end{array}$ & $\begin{array}{c}-0.004 \\
(0.980)\end{array}$ \\
\hline Adjusted $R^{2}$ & 0.085 & 0.062 & 0.114 \\
\hline
\end{tabular}

inversely related to the common main bank dummy. ${ }^{11}$ This result is driven mainly by observations from the 1990s. Indeed, in the 1980s a common main bank has a positive influence on bidder announcement returns, though the total and target returns are insignificant. However, in the 1990s both bidder and target firm returns are significantly negative when the firms share a common main bank. We also find that past profitability is positively related to announcement returns for both bidder as well as target firms, implying that mergers involving poorly performing firms are not rewarded by equity markets.

Interestingly, in nontabulated results we also find that mergers involving cross-industry targets yield significantly negative mean returns of $-8.9 \%$ and median returns of $-6.5 \%$. The CAR in intraindustry mergers is not significantly different from 0 , but the returns are statistically distinguishable from cross-industry mergers at the 5\% level. Overall, these results, coupled with the significantly

\footnotetext{
${ }^{11}$ We note that inferring causality here is tricky. Instead of common main banks "causing" poor returns, it may be possible that poor quality firms rely more on main banks.
} 
positive abnormal returns noted earlier, suggest the importance of creditor influence in orchestrating mergers to protect fixed claimants.

\section{Conclusions}

The market for corporate control in Japan behaves very different from that in the U.S. Using a sample of 91 mergers in the period 1982-2003, we document several distinctive features of this market in Japan. First we show that in stark contrast to the procyclical U.S. merger waves, mergers in Japan tend to be countercyclical, both with respect to the general economy as well as with respect to stock market valuations. Second, and again in contrast to the U.S. experience, we find that a significant fraction of Japanese bidder and target firms involve a common main bank. In such cases, a striking pattern emerges. When the bidder and target firms share a common main bank, mergers do not appear to create wealth for shareholders. Such mergers are also more likely to involve a weak and a financially strong merging partner, indicating that the main bank is primarily motivated to protect its own interests as creditor. Such mergers, as well as the negative AD wealth effects for target and bidder shareholders, are concentrated in the post-bubble era, that is, in the 1990s, when the broader Japanese economy slowed down for an extended period and main banks struggled with NPLs on their balance sheets.

Other distinctive features of Japanese mergers are the positive preannouncement returns accruing to both bidder and target firms, with bidders capturing approximately $1 / 2$ the gains that accrue to target firms, and the postannouncement period reversal of such gains. Overall, our results point to a market for corporate control that is distinctly less shareholder focused than that in the U.S. and where creditors play an important, perhaps dominant, role in corporate governance. Our study points to a cautionary approach in evaluating corporate governance models that rely on enhancing the welfare of creditors and other stakeholders in the belief that eventually such an approach will benefit shareholders.

\section{References}

Andrade, G.; M. Mitchell; and E. Stafford. "New Evidence and Perspectives on Mergers.” Journal of Economic Perspectives, 15 (2001), 103-120.

Andrade, G., and E. Stafford. "Investigating the Economic Role of Mergers." Journal of Corporate Finance, 10 (2004), 1-36.

Aoki, M. "Toward an Economic Model of the Japanese Firm." Journal of Economic Literature, 28 (1990), 1-27.

Aoki, M. Information, Corporate Governance, and Institutional Diversity: Competitiveness in Japan, the USA, and the Transitional Economies. Oxford, UK: Oxford University Press (2000).

Aoki, M.; H. Patrick; and P. Sheard. "The Japanese Main Bank System: An Introductory Overview." In The Japanese Main Bank System: Its Relevance for Developing and Transforming Economies, M. Aoki and H. Patrick, eds. Oxford, UK: Oxford University Press (1994).

Arikawa, Y., and H. Miyajima. "Understanding the M\&A Boom in Japan: What Drives Japanese M\&A?" Research Institute of Economy, Trade and Industry (RIETI) Discussion Paper 07-E-042 (2007).

Berkovitch, E., and M. P. Narayanan. "Motives for Takeovers: An Empirical Investigation.” Journal of Financial and Quantitative Analysis, 28 (1993), 347-362.

Bradley, M.; A. Desai; and E. H. Kim. "Synergistic Gains from Corporate Acquisitions and Their Division between the Stockholders of Target and Acquiring Firms." Journal of Financial Economics, 21 (1988), 3-40. 
Du Boff, R. B., and E. S. Herman. "The Promotional-Financial Dynamic of Merger Movements: A Historical Perspective." Journal of Economic Issues, 23 (1989), 107-133.

Flath, D. "Shareholding Interlocks in the Keiretsu, Japan's Financial Groups." Working Paper Series, Center on Japanese Economy and Business, Columbia University (1990).

Goergen, M., and L. Renneboog. "Shareholder Wealth Effects of European Domestic and CrossBorder Takeover Bids.” European Financial Management, 10 (2004), 9-45.

Hanazaki, M., and A. Horiuchi. "Is Japan's Financial System Efficient?" Oxford Review of Economic Policy, 16 (2000), 61-73.

Harford, J. "What Drives Merger Waves?” Journal of Financial Economics, 77 (2005), 529-560.

Hoshi, T.; A. Kashyap; and D. Scharfstein. "The Role of Banks in Reducing the Costs of Financial Distress in Japan.” Journal of Financial Economics, 27 (1990), 67-88.

Ito, K. "M\&A ni yoru Kigyo Kachi Souzou Kouka no Nichibei Hikaku" [Company Value Creation through M\&A: A Comparison between Japan and the U.S.]. Shōken Analyst Journal, 98.7 (1989), 11-23.

Jarrell, G. A., and A. B. Poulsen. "The Returns to Acquiring Firms in Tender Offers: Evidence from Three Decades." Financial Management, 18 (1989), 12-19.

Jensen, M. C., and R. S. Ruback. "The Market for Corporate Control: The Scientific Evidence." Journal of Financial Economics, 11 (1983), 5-50.

Kang, J.-K., and A. Shivdasani. "Does the Japanese Governance System Enhance Shareholder Wealth? Evidence from the Stock-Price Effects of Top Management Turnover.” Review of Financial Studies, 9 (1996), 1061-1095.

Kang, J.-K.; A. Shivdasani; and T. Yamada. "The Effect of Bank Relations on Investment Decisions: An Investigation of Japanese Takeover Bids.” Journal of Finance, 55 (2000), 2197-2218.

Kang, J.-K., and R. M. Stulz. "Do Banking Shocks Affect Borrowing Firm Performance? An Analysis of the Japanese Experience.” Journal of Business, 73 (2000), 1-23.

Kaplan, S. N. "Top Executive Rewards and Firm Performance: A Comparison of Japan and the United States.” Journal of Political Economy, 102 (1994), 510-546.

Kaplan, S. N., and M. S. Weisbach. "The Success of Acquisitions: Evidence from Divestitures." Journal of Finance, 47 (1992), 107-138.

Komoto, K. "Wagakuni no Kigyo Gappei no Tokutyo to Keizai Kouka" [The Characteristics of Japanese Mergers and Their Economic Effect]. Kokumin Keizai Zasshi, 186 (2002), 1-16.

Kruse, T. A.; H. Y. Park; K. Park; and K. Suzuki. "Long-Term Performance following Mergers of Japanese Companies: The Effect of Diversification and Affiliation." Pacific-Basin Finance Journal, 15 (2007), 154-172.

Langetieg, T. C. "An Application of a Three-Factor Performance Index to Measure Stockholder Gains from Merger.” Journal of Financial Economics, 6 (1978), 365-383.

Lin, B.-X.; D. Michayluk; H. R. Oppenheimer; and S. F. Reid. "Hubris amongst Japanese Bidders." Pacific-Basin Finance Journal, 16 (2008), 121-159.

Malmendier, U., and G. Tate. "Who Makes Acquisitions? CEO Overconfidence and the Market's Reaction.” Journal of Financial Economics, 89 (2008), 20-43.

Martynova, M., and L. D. R. Renneboog. "Mergers and Acquisitions in Europe." Tilburg University Discussion Paper, 6 (2006).

Melicher, R. W., and D. F. Rush. "Evidence on the Acquisition-Related Performance of Conglomerate Firms." Journal of Finance, 29 (1974), 141-149.

Mitchell, M. L., and J. H. Mulherin. "The Impact of Industry Shocks on Takeover and Restructuring Activity." Journal of Financial Economics, 41 (1996), 193-229.

Miyajima, H., and K. Fumiaki. "The Unwinding of Cross-Shareholding: Causes, Effects, and Implications." Research Institute of Economy, Trade and Industry (RIETI) Discussion Paper Series 05-E-006 (2005).

Morck, R., and M. Nakamura. "Banks and Corporate Control in Japan.” Journal of Finance, 54 (1999), 319-339.

Nelson, R. L. Merger Movements in American Industry, 1895-1956. Princeton, NJ: Princeton University Press (1959).

Pettway, R. H., and T. Yamada. "Mergers in Japan and Their Impacts upon Stockholders' Wealth." Financial Management, 15 (1986), 43-52.

Prowse, S. D. "Institutional Investment Patterns and Corporate Financial Behavior in the United States and Japan.” Journal of Financial Economics, 27 (1990), 43-66

Rhodes-Kropf, M., and S. Viswanathan. "Market Valuation and Merger Waves." Journal of Finance, 59 (2004), 2685-2718

Roll, R. "The Hubris Hypothesis of Corporate Takeovers." Journal of Business, 59 (1986), 197-216.

Scher, M. "Bank-Firm Cross-Shareholding in Japan: What Is It, Why Does It Matter, Is It Winding Down?" United Nations Department of Economic and Social Affairs Discussion Paper, 15 (2001). 
Servaes, H. “Tobin's Q and the Gains from Takeovers.” Journal of Finance, 46 (1991), 409-419.

Sheard, P. "The Main Bank System and Corporate Monitoring and Control in Japan." Journal of Economic Behavior and Organization, 11 (1989), 399-422.

Shleifer, A., and R. W. Vishny. "Stock Market Driven Acquisitions." Journal of Financial Economics, 70 (2003), 295-311.

Weston, J. F., and S. K. Mansinghka. "Tests of the Efficiency Performance of Conglomerate Firms." Journal of Finance, 26 (1971), 919-936.

Yeh, T.-M. "Bank Directorships and Bidder's Returns in Japanese Takeovers." Japanese Journal of Administrative Science, 20 (2007), 169-184.

Yeh, T.-M., and Y. Hoshino. "Productivity and Operating Performance of Japanese Merging Firms: Keiretsu-Related and Independent Mergers." Japan and the World Economy, 14 (2002), 347-366. 